\title{
Government Ideology, Democracy and the Sacrifice Ratio: Evidence from Latin American and Caribbean Disinflations
}

\author{
Tony Caporale*
}

Department of Economics \& Finance, University of Dayton, 300 College Park Dayton, OH 45469, USA

\begin{abstract}
This study uses a sample of 34 disinflations undertaken by thirteen Latin American and Caribbean (LAC) nations to test if political institutions impact the cost of policy induced disinflations. We find, after controlling for several of the most important covariates in the literature, that disinflations are less costly for right $v s$ left governments and that sacrifice ratios are lower for more democratic $v s$ authoritarian governmental regimes. This is robust to different measures of government ideology as well as to alternative ways of computing the sacrifice ratio and lends support for political economy literature which argues that political institutions have significant macroeconomic effects.
\end{abstract}

Keywords: Sacrifice ratio, disinflation, political regimes.

\section{INTRODUCTION}

Cross national differences in the output cost of policy induced disinflations (i.e. the sacrifice ratio) has been the focus of renewed interest in empirical monetary economics starting with Ball's [1] influential paper. Studies investigating the importance of such factors as trade openness, speed, size and length of disinflations, degrees of central bank independence, incomes policies, and nominal wage contracts on accounting for differences in the output costs of disinflations have been conducted by authors such as Walsh [2], Temple [3] and Daniels, Nourzad and VanHoose [4]. In a recent contribution, Caporale and Caporale [5] test whether the political composition of governments can explain differences in the costs of disinflations and find, for a sample of OECD economies, that governments from the political right face lower sacrifice ratios. They argue that this is due to such governments' stronger anti-inflation reputations, which renders disinflation policies undertaken during their tenure more credible.

One problem with drawing broad conclusions from the results of these previous studies is that their samples have been limited to a set of post-war developed democracies. This episode limitation has been addressed by Hofstetter [6] who computes the costs of disinflations for a sample of thirteen Latin American and Caribbean (LAC) nations covering the period 1973-2000. His nations were chosen due to their status as non-dollarized market driven economies with populations above two million people.

These episodes provide a unique setting in which to test if political institutions can help explain variations in measured sacrifice ratios. Since disinflationary periods are initiated by restrictive monetary (and often fiscal) policies,

\footnotetext{
*Address correspondence to this author at the Department of Economics \& Finance, University of Dayton, 300 College Park Dayton, OH 45469, USA; Tel: 9372292403; Fax: 9372292477; E-mail: caporale@udayton.edu
}

their costs depend on how quickly the inflationary expectations of price and wage setters adjust to those policies as well as agent forecasts of the credibility of such policy changes. Although Caporale and Caporale [5] classified government types using a binary right-left designation, LAC nations allow for a richer amount of variation in the designation of political regime type since many of the disinflations were conducted by (both leftwing and rightwing) non-democratic forms of government.

By statistically treating the Hofstetter [6] LAC disinflations as an unbalanced panel, we find, after controlling for several of the most important covariates in the literature, that disinflations are less costly in right $v s$ left governments and that sacrifice ratios are lower for more democratic $v s$ authoritarian governmental regimes. We show that these results are robust to different measures of government ideology as well as to alternative ways of computing the sacrifice ratio.

\section{MEASURING THE SACRIFICE RATIO}

Although the theory of a negative output-inflation tradeoff and the concept of the sacrifice ratio is an old one in macroeconomics, Ball's [1] notable contribution has proven particularly useful in quantifying this relationship. The ratio measures the sum of the differences between the logs of trend and actual output divided by the change in trend inflation during a given disinflation episode. It is interpreted as the output loss (or cost) of reducing inflation by one point. This measure best fits instances where the fall in trend inflation is the result of explicit contractionary aggregate demand policies.

Hofstetter [6] overcomes several shortcomings associated with the Ball [1] measurement of the sacrifice ratio for his sample of 13 LAC nations using data gathered from the Penn World Tables. Table 1 presents these disinflation episodes. One important modification, most relevant for these high inflation nations, is that whereas Ball only considers peak 
Table 1. Latin American and Caribbean Disinflation Episodes (1973-2000)

\begin{tabular}{|c|c|c|c|c|c|}
\hline Bolivia & 1990-1993 & 1995-1999 & & & \\
\hline Chile & $1985-1988$ & & & & \\
\hline Columbia & $1976-1978$ & $1980-1983$ & $1990-1996$ & & \\
\hline Costa Rica & 1991-1993 & 1995-1998 & & & \\
\hline Dominican Republic & $1974-1978$ & 1980-1982 & 1984-1986 & & \\
\hline Ecuador & $1974-1976$ & & & & \\
\hline Guatemala & 1974-1976 & 1986-1988 & 1996-1998 & & \\
\hline Honduras & 1973-1975 & 1979-1987 & 1990-1992 & & \\
\hline Jamaica & $1974-1976$ & 1978-1982 & $1984-1987$ & 1994-1998 & \\
\hline Mexico & $1974-1975$ & 1977-1978 & $1990-1993$ & & \\
\hline Paraguay & $1973-1975$ & 1979-1982 & 1993-1996 & & \\
\hline El Salvador & $1974-1976$ & 1980-1982 & 1986-1988 & 1989-1991 & $93-99$ \\
\hline Venezuela & $1980-1983$ & & & & \\
\hline
\end{tabular}

inflation rates at $20 \%$, Hofstetter expands the cases for peaks up to $30 \%$. He also, following Zhang [7], corrects for persistence effects by not requiring trend output to be at its actual level a year after the inflation trough. This allows for a long-run change in the natural rate of output thus resulting in a higher measured value for the sacrifice ratio than would be computed if such long-lived effects were ignored. Hofstetter also goes a step beyond Zhang's extension of the Ball [1] methodology by taking into account inflation inertia, thus allowing output to peak even before peak inflation.

In this study we use both of these measures of LAC sacrifice ratios as our dependent variable. We designate them the "Hofstetter" and "Zhang" sacrifice ratios, respectively. Summary statistics for these series are presented in Table $\mathbf{2}^{1}$ The mean value of the "Hofstetter" sacrifice ratio is .39 which indicates that a one point reduction in inflation led, on average, to a .39 point total decline in real GDP from trend. Importantly, the large standard deviation, (1.70), and range between their high and low values, (6.00 to -1.90), allow us to efficiently test several hypotheses concerning variation in the sacrifice ratio through time and across countries. We later check the robustness of our results using the "Zhang" measure.

\section{EMPIRICAL MODEL AND HYPOTHESES}

Given our limited degrees of freedom we test the significance of our political variables within the confines of a parsimoniously constructed model of the sacrifice ratio. Our model's variables include the initial level of inflation from which the disinflation began. Ball, Mankiw and Romer [8] predict that the sacrifice ratio should be decreasing in the initial level of trend inflation. They argue that this is because higher inflation reduces the level of nominal rigidity and steepens the short run Phillips Curve.

We also, following Ball [1], Temple [3], and Caporale \& Caporale [5], include the total change (or drop) in inflation in our model. Sargent [9] suggests that the size of the change

\footnotetext{
${ }^{1}$ We thank Marc Hofstetter for generously providing us with his data.
}

in inflation could be important since a large change may be perceived as a monetary policy regime shift, and thus could generate a shift in expectations, thereby lowering the sacrifice ratio.

Table 2. Macroeconomic and Political Summary Statistics (1973-2000)

\begin{tabular}{|l|c|c|c|c|}
\hline \multicolumn{1}{|c|}{ Variable } & Mean & St. Deviation & High & Low \\
\hline \hline Sacrifice ratio Hofstetter & 0.39 & 1.70 & 6.00 & -1.90 \\
\hline Sacrifice ratio Zhang & 0.35 & 1.43 & 5.20 & -1.20 \\
\hline Initial Inflation & 20.50 & 5.49 & 29.60 & 9.70 \\
\hline Inflation Drop & 11.15 & 4.76 & 21.20 & 4.10 \\
\hline Speed of Disinflation & 4.43 & 2.15 & 10.20 & 1.40 \\
\hline Length of Disinflation & 2.85 & 1.46 & 8.00 & 1.00 \\
\hline \% Right Government & 0.54 & 0.47 & 1.00 & 0.00 \\
\hline 100\% Right Dummy & 0.47 & 0.51 & 1.00 & 0.00 \\
\hline Polity 2 Index & 3.77 & 5.87 & 10.00 & -8.00 \\
\hline
\end{tabular}

Our final macroeconomic control variables (also drawn from Ball [1]) are the length (in terms of years) of the disinflations as well as a measure of the speed of disinflation. Speed is defined as the total change in inflation divided by the length of the disinflation. Sargent [9] argues that quicker (shorter) as well as faster (speedier) disinflations may be viewed as monetary regime shifts, resulting in a more rapid adjustment of expectations relative to longer (more gradual) movements. The faster expectations are altered, the lower the sacrifice ratio will be. An alternative hypothesis regarding the effect of speed is found in Taylor [10] who argues, using a staggered wage adjustment model that quick disinflations will reduce output but more gradual disinflations can be theoretically costless. ${ }^{2}$

\footnotetext{
${ }^{2}$ The empirical literature on the sacrifice ratio also tests for the importance
} of trade openness. Romer's [11] influential paper suggests that disinflations 
Table 3. Modeling the Sacrifice Ratio as an Unbalanced Panel

\begin{tabular}{|c|c|c|c|}
\hline \multirow{2}{*}{ Independent Variables } & \multirow{2}{*}{$\frac{\text { A. Regression with No Politics }}{\text { Eq. }^{*}}$} & \multicolumn{2}{|c|}{ B. Regressions with Political Regressors } \\
\hline & & Eq. $2^{* *}$ & Eq. $3^{* * * *}$ \\
\hline Constant & 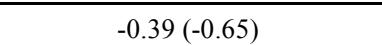 & $0.42(0.59)$ & $0.34(0.51)$ \\
\hline Percent Right Government & $\begin{array}{c}---- \\
---\end{array}$ & $-0.86(-3.22)$ & $\begin{array}{c}---- \\
---\end{array}$ \\
\hline 100\% Right Dummy & $\begin{array}{ll}---- \\
---1\end{array}$ & $\begin{array}{c}---- \\
---1\end{array}$ & $-0.89(-3.29)$ \\
\hline Polity 2 Index & $\begin{array}{c}---- \\
---\end{array}$ & $-0.14(-3.40)$ & $-0.14(-3.43)$ \\
\hline Initial Inflation & $0.12(1.22)$ & $0.10(0.97)$ & $0.10(1.03)$ \\
\hline Drop in Inflation & $-0.40(-4.08)$ & $-0.37(-3.24)$ & $-0.37(-3.24)$ \\
\hline Speed of Disinflation & $0.25(2.69)$ & $0.29(3.38)$ & $0.29(3.59)$ \\
\hline Length of Disinflation & $0.56(5.76)$ & $0.62(5.32)$ & $0.62(5.13)$ \\
\hline Adjusted $R^{2}$ & .09 & .12 & .12 \\
\hline Cross Section $\chi^{2}$ (p-value) & $21.35(.045)$ & $26.29(.01)$ & $24.48(.01)$ \\
\hline
\end{tabular}

Dependent Variable: Hofstetter Sacrifice Ratio ( $\mathrm{n}=34,13$ cross sections)

t-statistics are in parentheses.

Estimated using Panel Generalized Least Squares with White cross section standard errors and cross section fixed effects dummies (see Table 4).

Building on the work of Caporale and Caporale [5] we also investigate the importance of political factors in influencing the cost of disinflation. The significance of changes in political regimes in influencing macroeconomic outcomes been studied using rational partisan models (e.g. Alesina [12], Alesina and Roubini [13], Alesina, Roubini and Cohen [14]). In these models, conservative (or rightwing) governments are more inflation averse than liberal (or leftwing) governments and are thus more willing to engage in, or passively oversee, contractionary monetary policies (e.g., Grier [15]). The prediction of these models is that the probability and severity of recessions significantly rise with the establishment of a rightwing political regime.

The literature on the sacrifice ratio allows us to test the role that politics plays in influencing the cost of a given amount of disinflation. That is, the cost per point reduction of inflation (the sacrifice ratio) could well be lower under more conservative regimes since the public will view the disinflation policies of rightwing governments as more credible given their stronger anti-inflation reputations. Data on the nature of the different political regimes is obtained from Beck, Clarke, Keefer, Groff and Walsh [16] which categorizes governments using a "Right-Left" designation. We measure political stance using two different variables; the first, \% Right, is the percentage of each disinflation episode that had rightwing governance. The mean value in Table 2 shows that $54 \%$ of the total disinflation years occurred under rightwing governments.

Data from Table 2 also reveals that almost half (47\%) of disinflations were conducted solely under rightwing governments. This is shown in our alternative political variable, 100\% Right Dummy, which is equal to one if the government in power is classified as rightwing for the entire period of the disinflation and zero otherwise. Defining the

should be less costly in more open economies. We also experimented with including openness and found it to be consistently insignificant with its inclusion not affecting our other estimated parameters. These additional regressions are available upon request. variable in this way allows us to cleanly test whether disinflations begun, carried out and ended by rightwing governments have lower output costs per point drop in inflation than leftwing or political regime blends undertaking disinflations.

Our LAC sample enables us to test if democracy plays a role in explaining the costs of disinflation. This is a unique contribution to this literature that differs from the political economy model of Caporale and Caporale [5]. Unlike the developed OECD nations studied in most of the previous work on the sacrifice ratio, the regime types in our sample were rarely uniformly democratic. We measure the degree of democracy using a POLITY $2^{3}$ measure which ranges from +10 (strongly democratic) to -10 (strongly autocratic). Our hypothesis is that the cost of disinflation should be lower for more democratic governments since the openness of such regimes makes it less likely that the policy changes would come as a surprise and more likely that expectations shifts and price adjustments would occur more rapidly since policy changes should, at least in part, represent the preferences of the nation's voting blocks.

\section{STATISTICAL RESULTS}

In Table $\mathbf{3}$ we treat our dependent variable (the Hofstetter sacrifice ratio) as an unbalanced panel and estimate it using a fixed effects generalized least squares procedure with White cross sectional standard errors. This approach takes advantage of having repeated observations for each country by allowing the regression error variances to differ across nations. It also allows us to capture permanent differences between countries by including country specific dummy variables ${ }^{4}$.

Equation 1 shows that the initial level of inflation does not significantly influence the cost of LAC disinflations.

${ }^{3}$ Data was obtained from the POLITY IV (Project Integrated Network for Societal Conflict Research Program, Center for International Development and Conflict Management (CIDCM) www.cidem.undiedu/inscr/polity ${ }^{4} \mathrm{~A}$ Hausman test rejects a random effects model in favor of the fixed effects one presented. 
This is inconsistent with the Ball, Mankiw and Romer [8] conjecture but supports Ball's [1] empirical finding. The negative and significant coefficient on the drop in inflation supports Sargent's [9] argument that larger disinflations should be associated with those with lower costs since they would be viewed as signaling a move to a long-lasting, lower inflation environment.

We also find that the speed of disinflation positively and significantly (at greater than the .01 level) impacts the sacrifice ratio. This is opposite to the previous developed nation findings of Ball [1], Daniels, Nourzad and VanHoose [4], and Caporale and Caporale [5] and is consistent with the implication of Taylor's [10] staggered contract model. The data also revels that longer disinflations are found to be more costly, on average, than briefer more decisive ones.

Our $\chi^{2}$ statistics for each of the equations in Table 3 show that our fixed effects are all jointly significant at least the .05 level. The coefficients for the fixed effects models are shown in Table $\mathbf{4}$ and reveal that, after controlling for other explanatory variables, five of our 13 nations (Dominican Republic, Honduras, Jamaica, Paraguay and Venezuela) have intercept values (sacrifice ratios) that are higher than the group average. This supports the appropriateness of using the fixed effect framework to capture country specific heterogeneity.

Table 4. Cross Section Fixed Effects Coefficients

\begin{tabular}{|l|c|c|c|}
\hline \multicolumn{1}{|c|}{ Country } & Eq. 1 & Eq. 2 & Eq. 3 \\
\hline \hline Bolivia & -1.60 & -1.12 & -1.33 \\
\hline Chile & -2.21 & -2.86 & -2.82 \\
\hline Columbia & -1.94 & -1.14 & -1.54 \\
\hline Costa Rica & -0.58 & 0.24 & 0.30 \\
\hline Dominican Republic & 0.92 & 0.62 & 0.68 \\
\hline Ecuador & -1.86 & -2.64 & -2.58 \\
\hline Guatemala & -0.60 & -0.31 & -0.23 \\
\hline Honduras & 2.26 & 2.41 & 2.50 \\
\hline Jamaica & 1.72 & 2.22 & 2.22 \\
\hline Mexico & -0.71 & -2.00 & -1.97 \\
\hline Paraguay & 0.12 & -0.52 & -0.44 \\
\hline El Salvador & -0.05 & -0.33 & -0.27 \\
\hline Venezuela & 1.77 & 2.89 & 2.98 \\
\hline
\end{tabular}

Equation 2 (Table 3) tests our political hypothesis. It first shows that the incorporation of our political variables does not alter the signs or significance levels of our macroeconomic controls. The variable \% Right is found to negatively and significantly impact the sacrifice ratio, thus supporting, using our LAC sample of disinflations, both our credibility hypothesis as well as the developed nation findings of CC [2008]. Our political regime coefficient is quantitatively large; the standardized coefficient on \% Right is -24 , which indicates that a one standard deviation increase in it leads to a .24 standard deviation (or .40 point) decline in the sacrifice ratio. Our Polity 2 index of democracy also lowers the sacrifice ratio and is significant at better than the
.01 level. The standardized coefficient is -.48 , thus a one standard deviation (i.e. 5.87 point) increase in Polity 2 results in a .48 standard deviation (or .84 point) decline in the sacrifice ratio. These results demonstrate the importance of political factors in explaining cross-national and intertemporal differences in the cost of disinflations.

Equation 3 uses our $100 \%$ Right Dummy to measure political regime type. Supporting our credibility hypothesis, the statistical results show that rightwing governance has a negative and statistically significant impact on the sacrifice ratio. The Polity 2 index of democracy remains negative and significant and the signs and significance levels of our macroeconomic control variables are not sensitive to using this alternative political measure.

Table 5 tests if our results are sensitive to different methods of computing the sacrifice ratio (SR). As noted above, Hofstetter [6] also applies the Zhang [7] method to compute LAC sacrifice ratios which allows for a long-run change in the natural rate of output but does not factor in inflation inertia. The mean value of the series is .35 which indicates that each percentage point reduction in inflation led, on average, to a .35 $\%$ reduction in real GDP from potential.

Table 5. Political Regimes and Latin American Sacrifice Ratios

\begin{tabular}{|l|c|c|}
\hline \multicolumn{1}{|c|}{ Independent Variables } & Eq. . & Eq. . ${ }^{* *}$ \\
\hline \hline Constant & $1.38(3.28)$ & $1.26(3.47)$ \\
\hline Percent Right Government & $-1.02(-3.13)$ & ----- \\
\hline $\mathbf{1 0 0 \%}$ Right Dummy & ---- & $1.00(-2.83)$ \\
\hline Polity 2 Index & $-0.13(-3.80)$ & $-0.12(-3.76)$ \\
\hline Initial Inflation & $0.40(0.54)$ & $0.05(0.63)$ \\
\hline Drop in Inflation & $-0.22(-2.69)$ & $-0.23(-2.76)$ \\
\hline Speed of Disinflation & $0.13(1.38)$ & $0.13(1.42)$ \\
\hline Length of Disinflation & $0.37(5.86)$ & $0.36(5.45)$ \\
\hline $\mathbf{R}^{2}$ & .09 & .09 \\
\hline Cross Section $\chi^{2}$ (p-value) & $25.05(.01)$ & $25.11(.01)$ \\
\hline
\end{tabular}

Equation 4 uses the "Zhang" sacrifice ratio as our dependent variable in a fixed effects panel model that incorporates both our macroeconomic control and two key political exogenous variables. The results again indicate that more democratic and rightwing type governments are significantly associated with less costly disinflations. The quantitative effects of the political variables are very close to those found for the "Hofstetter" series. We also find that the sign and significance of our macroeconomic control variables remain the same, with the notable exception being that our coefficient for the speed of disinflations fails to achieve statistical significance. The country fixed effects continue to achieve joint statistical significance. The fixed effect dummies for equation 4 (presented in Table 6) reveal that five nations in our sample (Costa Rica, Dominican Republic, Honduras, Jamaica, Paraguay) have sacrifice ratios 
larger than the group average after controlling for the effects of our right hand side variables.

Table 6. Cross Section Fixed Effects Coefficients for Zhang Sacrifice Ratio Regressions

\begin{tabular}{|l|c|c|}
\hline \multicolumn{1}{|c|}{ Country } & Eq. 4 & Eq. 5 \\
\hline \hline Bolivia & -0.83 & -1.05 \\
\hline Chile & -1.86 & -1.82 \\
\hline Columbia & -0.67 & -1.16 \\
\hline Costa Rica & 0.24 & 0.31 \\
\hline Dominican Republic & 0.15 & 0.24 \\
\hline Ecuador & -1.88 & -1.81 \\
\hline Guatemala & -0.11 & -0.04 \\
\hline Honduras & 2.43 & 2.44 \\
\hline Jamaica & 1.64 & 1.65 \\
\hline Mexico & -2.01 & -1.94 \\
\hline Paraguay & 0.12 & -0.49 \\
\hline El Salvador & -0.26 & -0.19 \\
\hline Venezuela & 2.29 & 2.37 \\
\hline
\end{tabular}

Equation 5 substitutes our 100 Right Dummy measure of political regime for the continuous \% Right Government variable. The data reveals that our fixed effects model continues to achieve statistical significance and that larger disinflations lower, and longer ones increase, the "Zhang" LAC sacrifice ratio. We consistently find that rightwing governance and having higher Polity2 measures has a negative and statistically significant impact on the sacrifice ratio.

\section{CONCLUSION}

In contrast to most of the previous studies on the sacrifice ratio, we test if the costs of the disinflations for a sample of eighteen Latin American and Caribbean (LAC) nations covering the period 1973-2000, are influenced by the nature of political institutions. Following the developed nation study of Caporale and Caporale [5] our hypothesis is that sacrifice ratios should be lower under rightwing regimes since inflationary expectations of price and wage setters should adjust more quickly under such governments. We find, using two different methods of both computing the sacrifice ratio and measuring rightwing governance, strong support of this hypothesis.

In addition, since the regime types in our sample were rarely uniformly democratic, we test if the extent of democratic governance influences the cost of disinflation. Our statistical evidence reveals that democracies are associated with lower sacrifice ratios than more autocratic regimes. These results provide an additional source of confirmation for the growing political economy literature which argues that political institutions have significant macroeconomic effects ${ }^{5}$.

\section{ACKNOWLEDGEMENT}

I would like to thank Marc Hofstetter for generously sharing his data set with me

\section{REFERENCES}

[1] Ball L. What determines the sacrifice ratio? In: Mankiw NG, Ed Monetary Policy. Chicago: University of Chicago Press 1994; pp. $155-82$.

[2] Walsh C. Output-inflation trade-offs and central bank independence. Federal Reserve Bank of San Francisco Economic Letter 2002; 22: 1-10.

[3] Temple J. Openness, inflation, and the Phillips curve: a puzzle. J Money Credit Bank 2002; 34: 450-68.

[4] Daniels J, Nourzad P, VanHoose D. Openness, central bank independence, and the sacrifice ratio. J Money Credit Bank 2005; 37: 371-9.

[5] Caporale B, Caporale T. Political regimes and the cost of disinflation. J Money Credit Bank 2008; 40: 1541-4.

[6] Hofstetter M. Disinflations in Latin America and the caribbean: A free lunch? J Macroeconom 2008; 30: 327-45.

[7] Zhang H. Sacrifice ratios with long lived effects. Int Finance 2005; 8: 231-62.

[8] Ball LNG, Gregory M, Romer D. The new keynesian economics and the output-inflation tradeoff. Brook Pap Econ Act 1988; 1: 165.

[9] Sargent T. Stopping moderate inflations: the methods of Poincare and Thacher. In: Dornbush R, Ed. Inflation, Debt and Indexation Cambridge: MIT Press 1983: pp.1-41.

[10] Taylor J. Union wage settlements during a disinflation. American Econ Rev 1983; 73: 981-993.

[11] Romer D. Openness and inflation: theory and evidence. Q J Econ 1993; 108: 869-903.

[12] Alesina A. Macroeconomic policy in a two-party system as a repeated game. Q J Econ 1987; 102: 651-78.

[13] Alesina A, Roubini N. Political cycles in oecd economies. Rev Econ Stud1992; 59: 663-88.

[14] Alesina A, Roubini N, Cohen G. Political cycles in the macroeconomy Cambridge: MIT Press 1997.

[15] Grier K. Congressional influence on us monetary policy. J Monet Econ 1991; 28: 201-20.

[16] Beck T, Clark G, Groff A, Keefer P, Walsh P. New tools in comparative political economy: the database of political institutions. World Bank Econ Rev 2001; 15: 165-76.

[17] Drazen A. Political economy in macroeconomics. Princeton: Princeton University Press 2000.

${ }^{5}$ See, Drazen [17] for a comprehensive treatment of the macroeconomic political economy literature. 